\title{
SIMULATION OF RUDAL LAUNCH USING SUKHOI SU-35 AND VYMPEL R-73 3D MODELLING
}

\author{
Federiqo Ervan Novianto Dagomes ${ }^{1}$, Nurcahyani Dewi Retnowati², \\ Anggraini Kusumaningrum ${ }^{3}$ \\ Program Studi Teknik Informatika Sekolah Tinggi Teknologi Adisutjipto \\ Jl. Janti Blok R Adisucipto Yogyakarta \\ Federiqoervan4@gmail.com¹,ndewiret@gmail.com², anggraini.stta@gmail.com³
}

\begin{abstract}
The simulation is the operations imitating technique or processes that occur in the system and media, which can speed up the understanding of many things including missile launches. Missile launch simulation process on combat aircraft can be operated using computer simulation and application. The simulation is created using unity program and its buttons tested work fine. The results were tested with 10 questions to 10 flight department respondents. The data which is got showed $70.6 \%$ approached the process and missile launch function.
\end{abstract}

Keywords: Simulation, Missile Launch, Combat Aircraft

\section{Pengantar}

Simulasi sebagai mode untuk menghasilkan kondisi dari situasi dengan model untuk pembelajaran [1] dan dapat juga digunakan untuk mensimulasikan sesuatu hal sehingga dibutuhkan suatu model yang mewakili karakteristik objek [2]. Simulasi rudal merupakan sebuah simulasi yang pada awalnya sebuah pesawat diterbangkan dan pada posisi tertentu rudal ditembakkan karena adanya target pesawat musuh [3], dalam simulasi ini pesawat tersebut adalah pesawat Sukhoi SU-35 dan rudal yang ditembakkan jenis Vympel R-73. Sukhoi SU-35 merupakan pesawat tempur multiperan, kelas berat, berjelajah panjang, dan bertempat duduk tunggal serta berasal dari Rusia. Pesawat ini dikembangkan dari SU-27, dan awalnya diberi nama SU-27M. Pesawat ini dikembangkan untuk menandingi F-15 Eagle dan F-16 Fighting Falcon [4]. Pembuatan simulasi ini menggunakan software Unity 3D yang merupakan suatu software yang memang dapat digunakan dalam pemodelan objek tiga dimensi sekaligus mensimulasikan gerak objek tersebut [5]. Simulasi peluncuran rudal ini dapat digunakan oleh mahasiswa-mahasiswa teknik penerbangan dan bertujuan sebagai pembelajaran karena dapat memberikan informasi dan pengetahuan tentang bagaimana proses sebuah pesawat tempur meluncurkan rudal dan dapat memudahkan dalam memahami proses peluncuran rudal.

\section{Metodologi Penelitian}

Dalam pembuatan simulasi ini dilakukan dengan tahapan, tahap awal merupakan tahap desain atau perancangan yang dimulai dengan penentuan spesifikasi hardware dan software yang digunakan [6] dan menganalisis kebutuhan brainware.

Beberapa kebutuhan perangkat keras yang digunakan dalam pembuatan simulasi ini adalah pocessor AMD A4-5300 APU 3.40GHz, RAM 6.00 GB Harddisk 500GB dan VGA on Board.

Adapun spesifikasi software atau perangkat lunak yang digunakan dalam pembuatan simulasi ini adalah sistem Operasi Komputer (Windows 7 64bit),Unity 3D, Corel Draw x 7 
Brainware yang dibutuhkan dalam proses simulasi ini adalah bisa mengoperasikan komputer, Memiliki keingintahuan terhadap peluncuran rudal pesawat tempur dan dapat mengoperasikan aplikasi.

Tahap kedua dengan pembuatan flowchart (Gambar 1) untuk menggambarkan tahapan proses suatu sistem aplikasi. Program Flowchart menggambarkan bahasa untuk menspesifikasikan, membangun dan mendokumentasikan bagian dari informasi [7]. Selain itu, fungsi flowchart aadalah untuk mempresentasikan alur suatu program atau aplikasi sebelum program atau aplikasi tersebut dibuat.

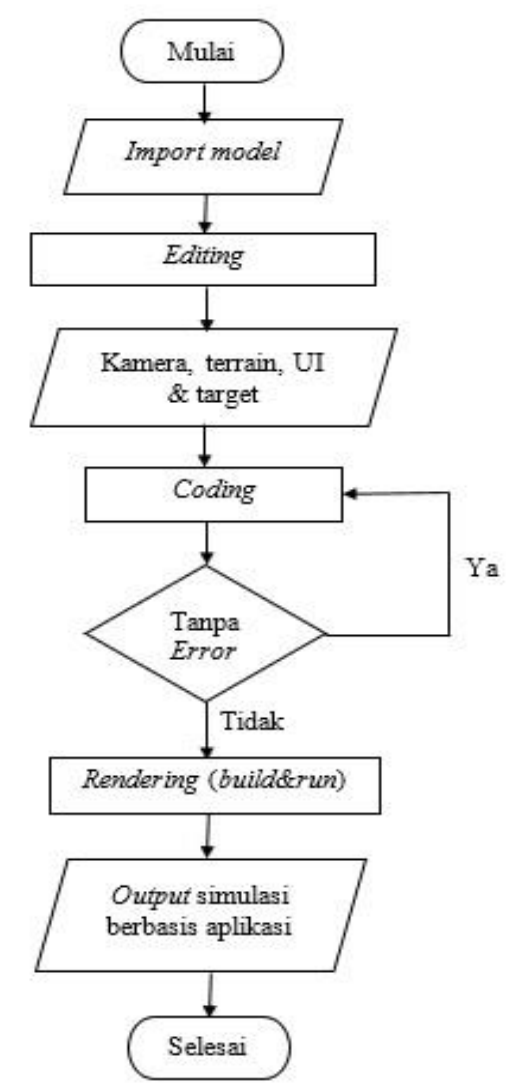

Gambar 1. Flowchart Pembuatan Simulasi

Pembuatan modeling pesawat terbang dan rudal mengikuti blueprint desain yang ada. Front View merupakan tampilan blueprint pesawat dari depan atau tampak depan. Gambar 2 merupakan Front view dari pesawat SU-35 [8].

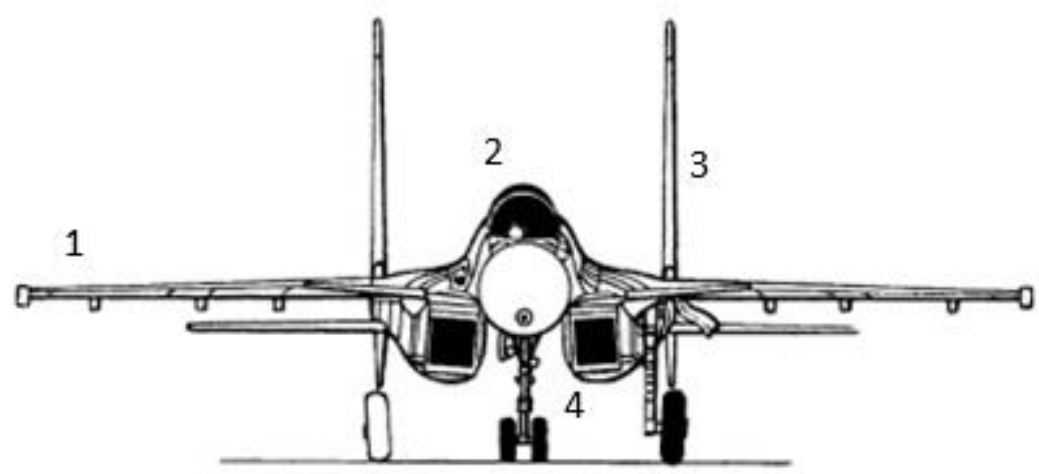

Gambar 2. Blueprint Front View Pesawat Sukhoi SU-35 
Keterangan:

1) Wing

2) Kokpit

3) Stabilator

4) Air Intake

Side view merupakan tampilan blueprint pesawat dari sisi samping kanan dan samping kiri. Gambar 3 merupakan side view dari pesawat SU-35 [8].

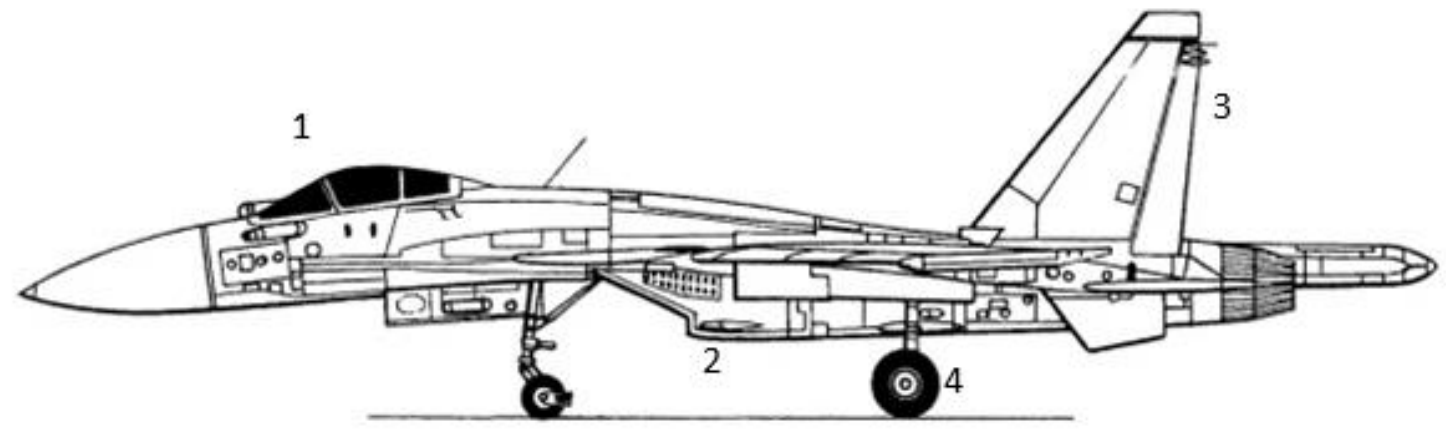

Gambar 3. Blueprint Side View Pesawat Sukhoi SU-35

Keterangan:

1) Kokpit

2) New RWR/Elint System

3) Rudder

4) Roda

Top view merupakan tampilan blueprint pesawat dari sisi atas atau tampak atas. Gambar 4. merupakan blueprint top view dari pesawat SU-35 [8].

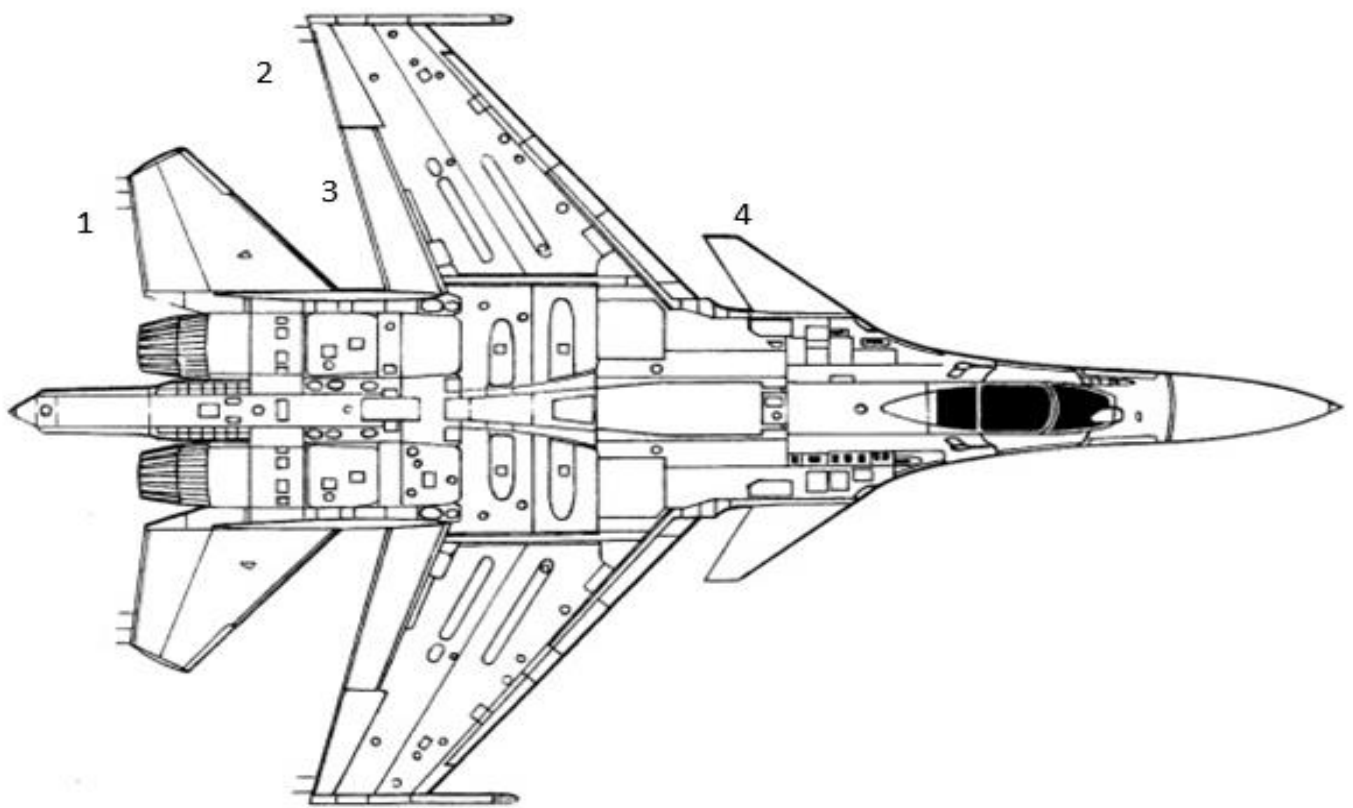

Gambar 4. Top View.

Keterangan:
1) Elevator
2) Aileron
3) Flap 


\section{4) Stabilizer}

Pembuatan modeling rudal juga menggunakan blueprint dan terdiri dari front view dan side view. Front View (Gambar 5) merupakan tampilan blueprint rudal/roket dari depan atau tampak depan [9].

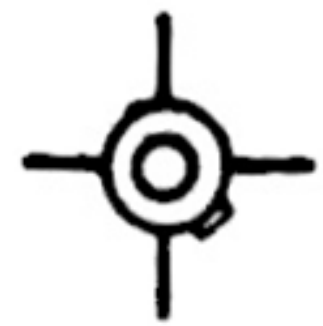

Gambar 5. Blueprint Front View Rudal Vympel R-73

Side view (Gambar 6) merupakan tampilan blueprint rudal/roket dari sisi samping kanan dan samping kiri [9].

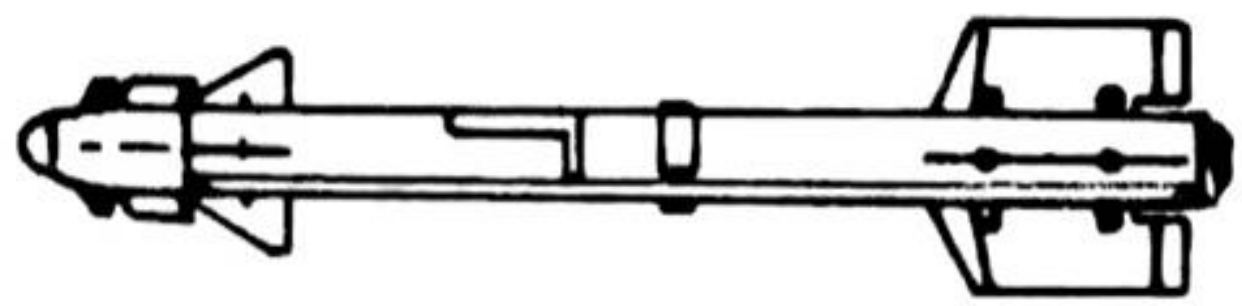

Gambar 6. Blueprint Side View Rudal Vympel R-73

\section{Hasil dan Pembahasan}

\subsection{Tampilan Menu}

Menu utama (Gambar 1) adalah halaman awal daripada sebuah aplikasi dan memiliki beberapa menu lagi didalamnya. Dalam rancangan ini menunjukkan user interface menu utama pada aplikasi simulasi. Terdapat 4 tombol yang dapat memanggil fungsinya masingmasing. Untuk tombol start simulasi berfungsi menjalankan simulasi peluncuran rudal. Tombol how to play dapat memanggil menu how to play yang berisi cara menjalankan simulasi peluncuran rudal. Kemudian tombol Credit berfungsi memanggil menu credit yang berisi penjelasan tentang rudal/roket. Sedangkan tombol quit berfungsi untuk menutup atau keluar aplikasi. Gambar 7 merupakan tampilan user interface menu utama penerapan model 3 dimensi pesawat Sukhoi SU-35 dan Vympel R-73 untuk simulasi peluncuran rudal.

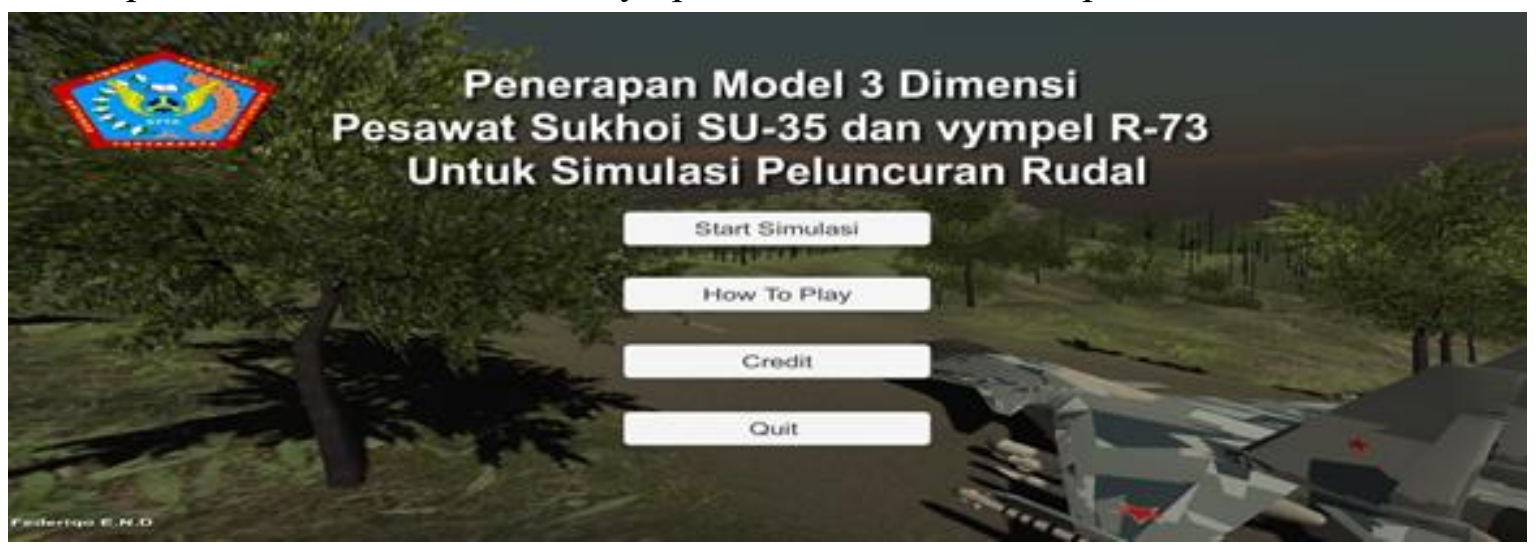

Gambar 7. Tampilan Menu Utama 
Menu how to play (Gambar 8) adalah halaman dimana terdapat penjelasan tentang cara pengoperasian atau memainkan aplikasi penerapan model 3 dimensi pesawat Sukhoi SU35 dan vympel R-73 untuk simulasi peluncuran rudal. Pada menu how to play terdapat 1 tombol yang berfungsi untuk kembali ke menu utama. Berikut adalah tampilan user interface menu how to play.

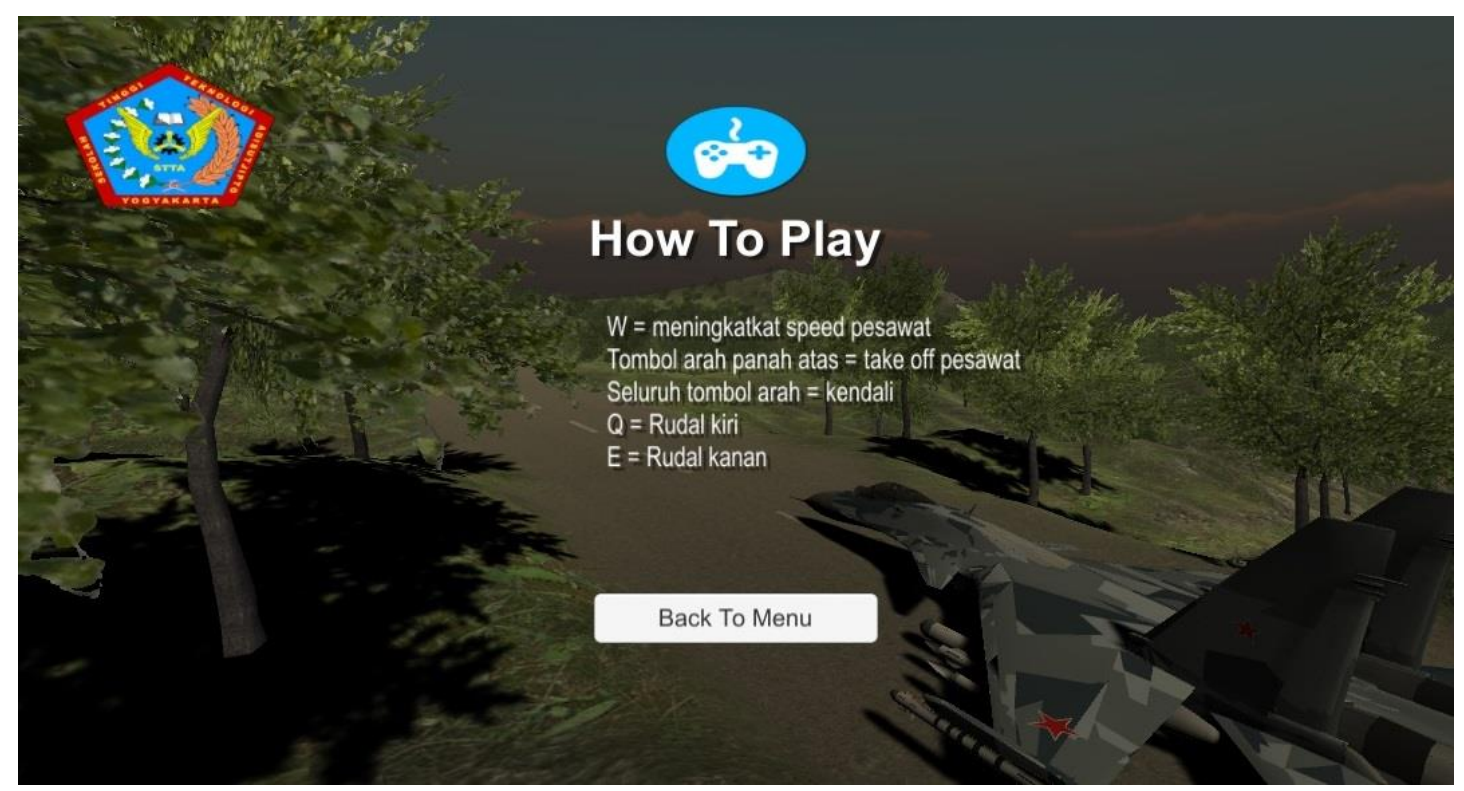

Gambar 8. Tampilan Menu How To Play

Pada aplikasi penerapan model 3 dimensi pesawat Sukhoi SU-35 dan Vympel R-73 untuk simulasi peluncuran rudal terdapat terrain sebagai ground, 1 set pesawat SU-35 beserta aksesoris yaitu rudal, missile dan efek partikel, lighting, dan target dari rudal R-73. Simulasi peluncuran rudal ini juga terdapat sistem take off dan landing. Tombol "W" pada keyboard berfungsi sebagai akselerasi dan tombol "Q" dan "E" berfungsi sebagai tombol peluncuran rudal. Sedangkan untuk mengontrol arah geraknya menggunakan tombol arah $(\leftarrow \uparrow \rightarrow \downarrow)$ pada keyboard. Gambar 9 merupakan tampilan aplikasi penerapan model 3 dimensi pesawat Sukhoi SU-35 dan vympel R-73 untuk simulasi peluncuran rudal. 


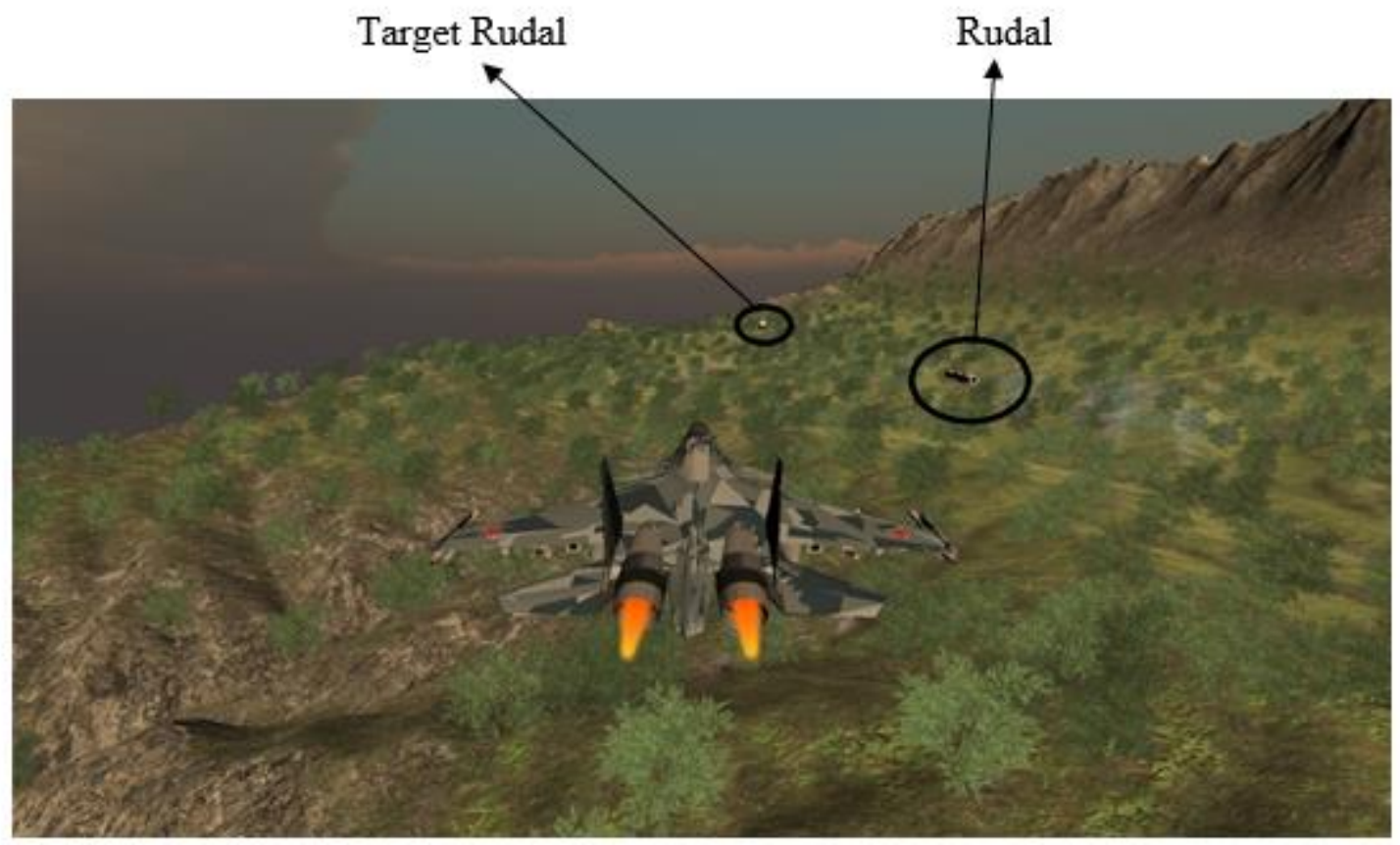

Gambar 9. Tampilan Simulasi Peluncuran Rudal

\subsection{Pengujian}

Pengujian yang dilakukan ada dua jenis yaitu pengujian dari fungsi simulasi dan pengujian responden. Pengujian fungsi simulasi (Tabel 1) dilakukan dengan melakukan pengecekan apakah tombol-tombol how to play dan button pada simulasi yang ada pada tampilan menu utama, tampilan menu credit, Tombol akselerasi "W" dan arah panah atas " $\uparrow "$ takeoff, Belok kiri tombol arah panah kiri "๘”,Belok kanan tombol arah panah kanan “ $\rightarrow$ ",Turun tombol arah panah bawah " $\downarrow$ ",Tombol peluncuran rudal "Q" dan "E", Tombol Esc "pause", dan fungsi Landing dengan melepas tombol akselerasi "W".

Tabel 1. Uji Fungsi Simulasi

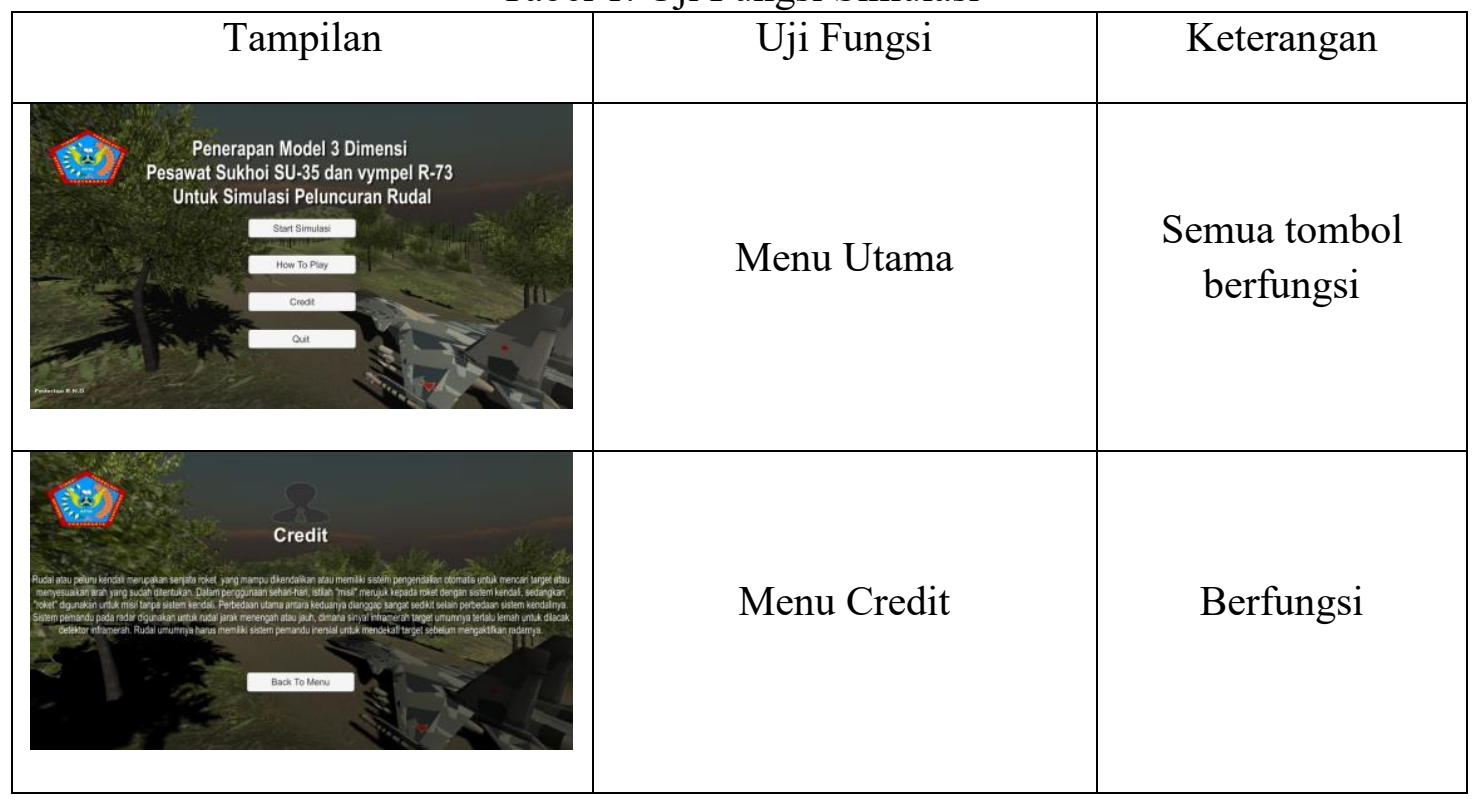




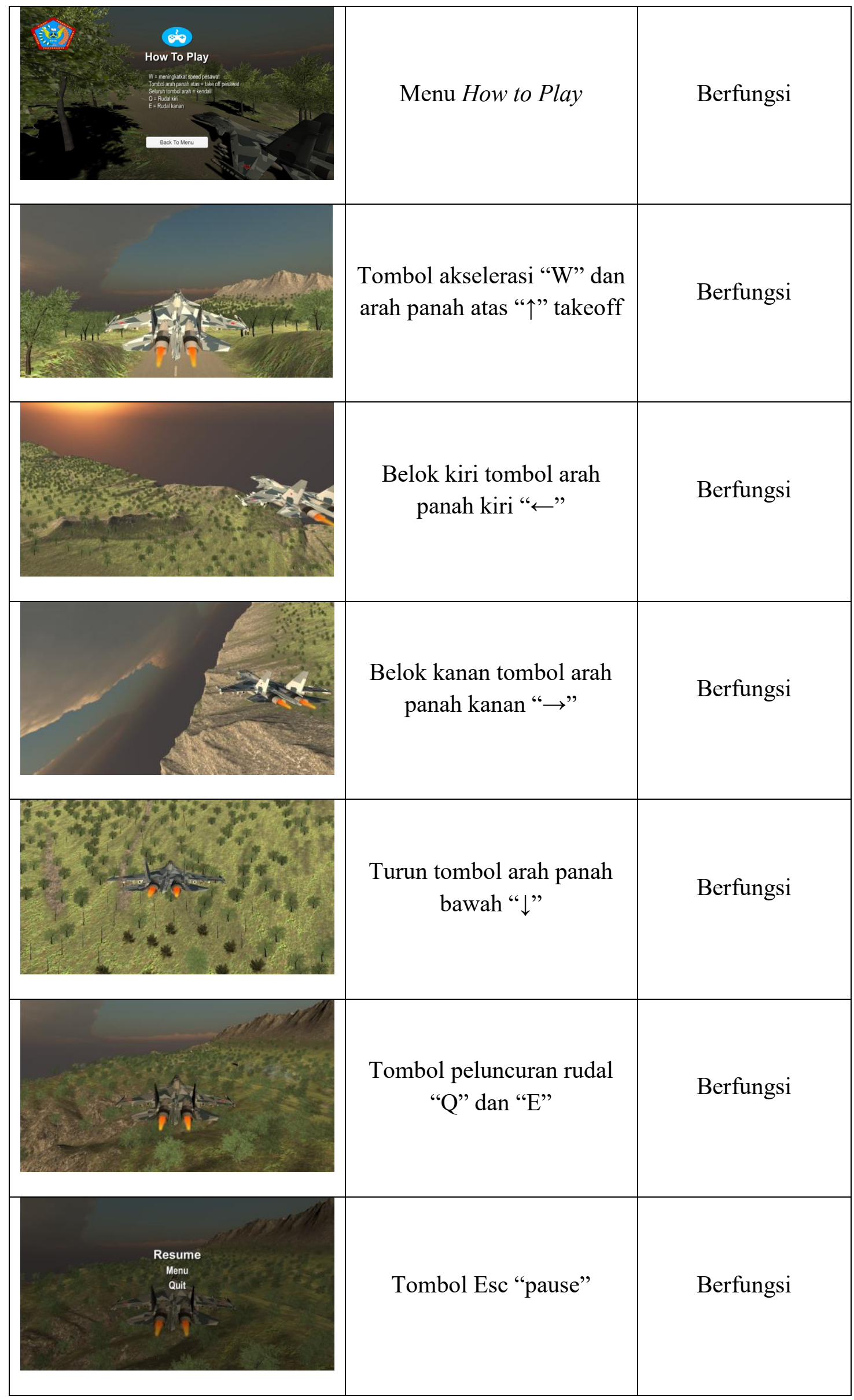




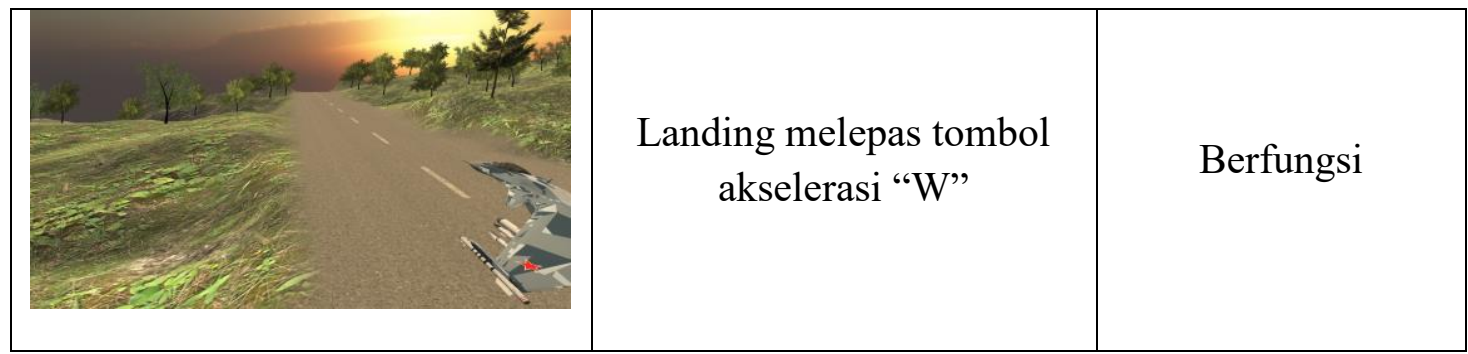

Pengujian yang kedua adalah dengan menggunakan kuosioner dan responden. Pengumpulan data diperoleh melalui kuesioner yang dirumuskan berdasarkan teori dan pendapat ahli dan diisi oleh responden yang kemudian diolah menjadi sebuah informasi. Responden yang dilibatkan dalam pengambilan data sebanyak 10 orang yaitu 10 dosen Teknik Penerbangan.

Pengukuran yang dilakukan terhadap para ahli menggunakan skala Likert [10] dengan penilaian skor $5=$ sangat baik, skor $4=$ baik, skor $3=$ cukup, skor $2=$ kurang, skor $1=$ kurang baik.

Tabel 2 merupakan tabel kuesioner dengan 10 pertanyaan yang telah diisi oleh 10 orang responden pada penerapan model 3 dimensi pesawat Sukhoi SU-35 dan vympel R-73 untuk simulasi peluncuran rudal.

Tabel 2. Hasil Kuosioner

\begin{tabular}{|c|c|c|c|c|c|c|}
\hline \multirow[t]{2}{*}{ No } & \multirow[t]{2}{*}{ Pertanyaan } & \multicolumn{5}{|c|}{ Pilih Jawaban } \\
\hline & & 1 & 2 & 3 & 4 & 5 \\
\hline 1 & $\begin{array}{l}\text { Bagaimana pendapat anda tentang interface awal / } \\
\text { menu utama, sebelum memulai simulasi ini? }\end{array}$ & 0 & 0 & 1 & 8 & 1 \\
\hline 2 & $\begin{array}{l}\text { Bagaimana pendapat anda tentang system kendali } \\
\text { pesawat terbang pada simulasi ini? }\end{array}$ & 0 & 0 & 6 & 3 & 1 \\
\hline 3 & $\begin{array}{l}\text { Bagaimana pendapat anda tentang design pesawat } \\
\text { yang digunakan pada simulasi ini? }\end{array}$ & 0 & 0 & 2 & 6 & 2 \\
\hline 4 & $\begin{array}{l}\text { Bagaimana pendapat anda tentang visualisasi yang } \\
\text { ada dalam simulasi ini? }\end{array}$ & 0 & 0 & 6 & 3 & 1 \\
\hline 5 & Apakah menurut anda simulasi ini user friendly? & 0 & 0 & 3 & 5 & 2 \\
\hline 6 & Apakah simulasi ini telah sesuai kriteria? & 0 & 1 & 6 & 2 & 0 \\
\hline 7 & $\begin{array}{l}\text { Bagaimana pendapat anda secara keseluruhan } \\
\text { simulasi peluncuran rudal pada pesawat tempur ini? }\end{array}$ & 0 & 1 & 5 & 3 & 1 \\
\hline 8 & Apakah audio di dalam simulasi telah sesuai? & 0 & 1 & 7 & 2 & 0 \\
\hline 9 & $\begin{array}{l}\text { Bagaimana pendapat anda tentang kelancaran proses } \\
\text { simulasi ini? }\end{array}$ & 0 & 1 & 4 & 4 & 1 \\
\hline 10 & Pahamkah anda dengan simulasi ini? & 0 & 0 & 5 & 4 & 1 \\
\hline
\end{tabular}


Mendapatkan hasil jawaban sebagai berikut :
1) Sangat Baik $=10$
2) $\quad$ Baik $=40$
3) $\quad$ Cukup $=45$
4) Kurang $=4$
5) Kurang Baik $=0$

Pengukuran hasil kuosioner tersebut dengan menggunakan Rumus Skala Likert $=\mathrm{T}$ x Pn, di mana $\mathrm{T}$ adalah total jumlah responden yang memilih, dan Pn adalah Bobot Nilai. Hasil perhitungan yang didapatkan sebagai berikut:

1) Responden yang menjawab sangat baik $(5)=10 \times 5=50$

2) Responden yang menjawab baik (4) $=40 \times 4=160$

3) Responden yang menjawab cukup (3) $=45 \times 3=135$

4) Responden yang menjawab kurang (2) $=4 \times 2=8$

5) Responden yang menjawab kurang baik (1) $=0 \times 1=0$

Total Skor $=353$

Langkah selanjutnya adalah melakukan interpretasi skor perhitungan. Untuk mendapatkan hasil interpretasi, harus diketahui dulu skor tertinggi (Y) dan skor terendah (X) untuk item penilaian dengan rumus sebagai berikut :

$\mathrm{Y}=$ Skor tertinggi likert $\mathrm{x}$ jumlah responden (Angka Tertinggi 5)" Perhatikan Bobot Nilai" $\mathrm{X}=$ Skor terendah likert $\mathrm{x}$ jumlah responden (Angka Tertinggi 1)" Perhatikan Bobot Nilai"

Jumlah skor tertinggi untuk item SANGAT BAIK ialah $5 \times 10=50 \times(10$ pertanyaan $)$ $=500$, sedangkan item KURANG BAIK ialah $1 \times 10=10 \times(10$ pertanyaan $)=100$. Jadi, jika total skor responden diperoleh angka 353, maka penilaian interpretasi responden terhadap media pembelajaran tersebut adalah hasil nilai yang dihasilkan dengan menggunakan rumus Index $\%$.

Perhitungan selanjutnya dilakukan untuk mengetahui interval (jarak) dan interpretasi persen agar mengetahui penilaian dengan metode mencari Interval skor persen (I).

Rumus Interval

$\mathrm{I}=100 /$ Jumlah skor(likert)

$\mathrm{I}=100 / 5=20$

Hasil (I) $=20$

(Ini adalah interval jarak dari terendah $0 \%$ hingga tertinggi 100\%).

Hasil perhitungan dengan rumus interval didapatkan persentase nilai yang dapat dilihat pada Tabel 3 .

Tabel 3. Persentase Nilai.

\begin{tabular}{|c|l|}
\hline $0 \%-19.99 \%$ & Kurang Baik \\
\hline $20 \%-39.99 \%$ & Kurang \\
\hline $40 \%-59.99 \%$ & Cukup \\
\hline $60 \%-79.99 \%$ & Baik \\
\hline $80 \%-100 \%$ & Sangat Baik \\
\hline
\end{tabular}

Perhitungan berikutnya adalah menghitung Index dengan menggunakan rumus Index = Total Skor / Y x 100

Index $=$ Total skor $/ Y$ x $100=353 / 500 \times 100=70.6 \%$

Pengujian menggunakan kuesioner dan dihitung dengan metode skala likert adalah $70.6 \%$, maka dapat disimpulkan bahwa pengujian menggunakan kuesioner termasuk dalam kriteria "Baik". 


\subsection{Pembahasan}

Adapun kelebihan dan kekurangan dari aplikasi Penerapan Model 3 Dimensi Pesawat Sukhoi SU-35 Dan Vympel R-73 Untuk Simulasi Peluncuran Rudal yang dibuat menggunakan Unity yaitu:

a. Kelebihannya adalah kualitas detail pada model 3 dimensi terjaga, user friendly. terdapat sistem lighting, sound dan beberapa efek visual.

b. Kekurangannyab adalah terrain yang disediakan kurang luas, sistem kamera kurang menarik, input script pada simulasi dilakukan manual.

\section{Kesimpulan}

Kesimpulan dari penelitian ini adalah: a) gerakan take off dan landing telah sesuai dengan fungsi pesawat terbang, b) pergerakan rudal R-73 telah sesuai dengan fungsi pada rudal c)pengujian fungsi simulasi pada setiap menu dan tombol semua berfungsi d) pengujian menggunakan kuesioner dengan 10 responden dan 10 pertanyaan dan dihitung dengan metode skala likert adalah $70.6 \%$, dilihat dari persentase nilai yang dihitung dengan menggunakan rumus interval, simulasi ini masuk kriteria "Baik" sehingga simulasi ini dapat digunakan untuk pembelajaran.

\section{Daftar Pustaka}

[1] Ekoanindiyo, F. A. 2011. Pemodelan Sistem Antrian Dengan Menggunakan Simulasi. Jurnal Ilmiah Dinamika Teknik, 5(1).

[2] Retnowati, N. D., \& Mardhatillah, Z. 2015. Simulasi Self Defense sebagai Sarana Pembelajaran Menghadapi Pembajakan Pesawat Komersial Menggunakan Metode Frame By Frame. Compiler, 4(2).

[3] Andiarti, R. 2010. Kontroler Gain Scheduling untuk Rudal Udara ke Udara. Jurnal Teknologi Dirgantara, 3(2).

[4] Maulana, B. 2017. Dampak Peningkatan Perdagangan Bilateral Indonesia-Rusia Terhadap Investasi Rusia Di Indonesia (Doctoral Dissertation, Perpustakaan).

[5] Yang, K., \& Jie, J. 2011. The designing of training simulation system based on unity 3D. In 2011 Fourth International Conference on Intelligent Computation Technology and Automation (Vol. 1, pp. 976-978). IEEE.

[6] Retnowati, N. D., \& Nugraheny, D. 2020. Virtual Tour Of Sadeng Beach Tourism Route Using The Multimedia Development Life Cycle Method. Angkasa: Jurnal Ilmiah Bidang Teknologi, 12(1).

[7] PRANANDA, R. 2014. Simulasi Penembakan Rudal Yakhont Oleh Kapal Frigrate Dan Manuver Cobra Pugachev Oleh Pesawat Tempur.

[8] Outlines. Sukhoi SU-35 Flanker blueprints free. Online: https://getoutlines.com/blueprints/18028/sukhoi-su-35-flanker-blueprints, Diakses 27 Februari 2020.

[9] A. Ziyadi. 2016. Mengenal Rudal Vympel R-73 TNI AU. Online: https://militermeter.com/mengenal-rudal-vympel-r-73-tni-au/. Diakses pada 27 Februari 2020.

[10] Retnawati, H. 2015. Perbandingan akurasi penggunaan skala likert dan pilihan ganda untuk mengukur self-regulated learning. Jurnal Kependidikan: Penelitian Inovasi Pembelajaran, 45(2). 